Syntax Literate : Jurnal Ilmiah Indonesia p-ISSN: 2541-0849 e-ISSN : 2548-1398

Vol. 4, No. 9 September 2019

\title{
PENGARUH PENGAWAS DAN DIREKSI WANITA TERHADAP RISIKO BANK DENGAN KEKUASAAN CEO SEBAGAI VARIABEL PEMODERASI (STUDI BANK UMUM INDONESIA)
}

\section{Lilik Rohmawati}

Sekolah Tinggi Ilmu Ekonomi (STIE) As Sholeh Pemalang

Email: lilikrohmawati021@gmail.com

\begin{abstract}
Abstrak
Penelitian ini bertujuan untuk mengisi gap empiris dengan menjelasan pengaruh kekuasaan CEO terhadap hubungan antara persentase pengawas dan direksi wanita dengan risiko bank. CEO merupakan individu yang paling berpengaruh terhadap pengambilan keputusan perusahaan, sehingga pengaruh dari kekuasaan CEO akan lebih terlihat jelas dalam output perbankan. Sampel Penelitian ini adalah seluruh Bank Umum di Indonesia pada periode 2012-2017 yang tedaftar di Bursa Efek Indonesia. Risiko Bank dalam penelitian ini diukur dengan menggunakan nilai z-score. Pengawas dan direksi wanita diukur dengan menggunakan persentase komisaris dan direktur wanita dibandingkan dengan jumlah komisaris total. Kekuasaan CEO diukur dengan dua proksi yaitu kepemilikan saham CEO dan CEO tenure. Analisis yang digunakan adalah analisis regresi dengan total observasi Bank Umum sebanyak 158 selama periode 5 tahun. Berdasarkan hasil penelitian ini persentase, pengawas dan direksi wanita berpengaruh signifikan untuk mengurangi risiko bank. Temuan penelitian ini juga membuktikan bahwa CEO tenure yang tinggi akan memperlemah hubungan antara persentase pengawas dan direksi wanita dengan risiko bank. Sedangan kepemilika saham CEO tidak terbukti memperkuat hubungan antara persentase pengawas dan direksi wanita dengan risiko bank.
\end{abstract}

Kata kunci : pengawas dan direksi wanita, kekuasaan CEO, risiko bank

\section{Pendahuluan}

Bank adalah sebuah lembaga intermediasi keuangan, umumnya didirikan dengan kewenangan untuk menerima simpanan uang, meminjamkan uang, dan menerbitkan promes atau yang dikenal sebagai bank note (Munajim \& Anwar, 2016). Penelitian mengenai tema risiko bank sangat menarik untuk diteliti. Hasil survei yang dilaksanakan oleh (PricewaterhouseCoopers, 2008) menemukan bahwa faktor-faktor yang mempengaruhi krisis keuangan disebabkan oleh budaya dan pengambilan risiko yang berlebihan di bank. (Greuning, H. v., dan Bratanovic, 2009) mengungkapkan bahwa korelasi antara berbagai risiko dalam satu bank dan keseluruhan sistem 
perbankan sangat kompleks sehingga dapat memicu terjadinya krisis. Krisis di lembaga keuangan mempengaruhi kerapuhan sistem ekonomi, fluktuasi siklus bisnis dan pertumbuhan ekonomi (Laeven \& Levine, 2009). Krisis keuangan yang terjadi merupakan bukti bahwa risiko bank sangat penting dalam menentukan stabilitas keuangan.

Penelitian ini bertujuan untuk memperkaya pemahaman tentang risiko bank dengan menguji salah satu karakteristik manajerial yaitu perbedaan jenis kelamin (sex difference) dari manajemen tingkat atas bank dan pengaruhnya terhadap pengambilan risiko bank. Wanita dan laki-laki bertindak dan berperilaku berbeda. Perbedaan sikap dan perilaku ini telah banyak didokumentasikan dalam literatur psikologi maupun ekonomi yang sering dikaitkan dengan perbedaan memproses informasi, kehati-hatian, kepercayaan diri dan pengambilan risiko (Bernasek \& Shwiff, 2001) (Huang \& Kisgen, 2013).

Motivasi dilakukannya penelitian ini yaitu pertama, wanita memiliki peran yang signifikan terhadap tata kelola perusahaan seperti yang diungkapkan oleh (Adams \& Ferreira, 2009). Wanita memiliki kecenderungan lebih independen, memiliki CEO tenure yang lebih pendek, dan mengurangi kecenderungan perusahaan untuk melakukan restatement atau pelaporan ulang (Abbott, Parker, \& Presley, 2012). Wanita melakukan pengungkapan laporan sosial perusahaan yang lebih tinggi serta meningkatkan nilai budaya di perusahaan (Larkin, M. B., Bernardi, R. A., dan Susan M, 2013). Perilaku etis wanita juga tercermin dalam kecenderungan $\mathrm{CFO}$ wanita yang lebih rendah dalam melakukan agresivitas pajak dibandingkan dengan CFO laki-laki (Francis, Hasan, Wu, \& Yan, 2014). Berdasarkan pada karakteristik wanita yang telah ditemukan dalam penelitian terdahulu eksekutif wanita berpengaruh negatif terhadap risiko bank. Wanita berperan penting dalam mempertimbangan isu perusahaan secara komprehensif, memunculkan lebih banyak pertentangan dan pengakuan dari sudut pandang yang lebih luas dan menciptakan proses pengambilan keputusan yang lebih lambat, memicu diskusi dan pemikiran kelompok, serta memiliki karakteristik kurang percaya diri, berhati-hati, kurang agresif dan pengambilan keputusan yang etis

Kedua, penelitian terkait dengan keberagaman board wanita terhadap risiko bank telah banyak dilakukan akan tetapi bukti menunjukkan hasil yang tidak konklusif. 
Pahvia, Vahamaa dan Vahamaa melakukan penelitian dengan sampel CEO dan chairperson wanita di bank Amerika. Hasil penelitian Pahvia, Vahamaa dan Vahamaa menunjukkan bahwa bank dengan CEO maupun chairperson wanita lebih hati-hati dan menahan level modal yang lebih tinggi serta dapat mengurangi risiko pada kondisi kejenuhan pasar. Sejalan dengan penelitian tersebut, mengungkapkan bahwa bank yang dipimpin oleh CEO wanita berkaitan dengan risiko bank yang lebih rendah, memiliki kecukupan modal dengan rasio modal terhadap aset yang lebih tinggi.

Berbeda dengan hasil penelitian yang menemukan bahwa board wanita berpengaruh negatif terhadap risiko bank, (Bollen \& Posavac, 2018) menemukan bahwa pada sampel penelitian mahasiswa, laki-laki memilih untuk merekomendasikan aset yang lebih berisiko dibandingkan dengan mahasiswa wanita yang konsisten dengan preferensi wanita yang menghidari resiko. Sebaliknya pada sampel profesional, manajer merekomendasikan aset yang sama, menunjukkan bahwa pengambilan risiko antara laki-laki dan wanita tidak berbeda. Hasil yang berbeda ditunjukkan oleh penelitian yang dilakukan oleh (Zigraiova \& Jakubik, 2015), mengungkapkan bahwa keberadaaan board wanita berpengaruh positif terhadap risiko bank yang berarti bahwa keberadaan wanita di eksekutif meningkatkan risiko bank.

Penelitian terdahulu melihat keberadaan board wanita sebagai karakteristik "individu" yang menghindari risiko dan mengabaikan hubungan secara keseluruhan interaksi antara pengawas dan direksi serta anggota manajemen tingkat atas perusahaan dalam konteks pengambilan keputusan (Park, Kim, Chang, Lee, \& Sung, 2018). (Hambrick \& Mason, 1984) mengungkapkan bahwa kelompok manajemen tingkat atas perusahaan berperan penting dalam menentukan strategi dan pengambilan keputusan. Keputusan tersebut merupakan hasil interaksi antara kekuasaan manajerial dan kelompok manajemen tingkat atas perusahaan dalam menentukan kinerja organisasi (Finkelstein, Cannella, Hambrick, \& Cannella, 2009).

Penelitian ini bertujuan untuk mengisi gap empiris dengan menjelasan hal tersebut melalui pengaruh kekuasaan CEO terhadap hubungan antara persentase pengawas dan direksi wanita dengan risiko bank. (Kim, 2010) mengungkapkan bahwa CEO merupakan individu yang paling berpengaruh terhadap pengambilan keputusan perusahaan, sehingga pengaruh dari kekuasaan CEO akan lebih terlihat jelas dalam 
output perbankan. Kekuasaan CEO meningkat seiring dengan bertambahnya tenure dan kepemilikan saham (Park et al., 2018).

Semakin lama CEO menjabat di perusahaan, CEO memperoleh keahlian manajerial, memperoleh informasi yang komprehensif, mengembangkan hubungan dengan direktur dan mempunyai pengaruh yang dipertimbangkan terhadap board (Walters, Kroll, \& Wright, 2010). CEO juga dapat meningkatkan kekuasaan dengan memiliki sejumlah saham diperusahaan, semakin tinggi saham yang dimiliki oleh perusahaan menjadikan CEO semakin berkuasa menyebabkan berkurangnya pengawasan yang dilakukan oleh board (Finkelstein et al., 2009) (Fahlenbrach \& Stulz, 2009). Kekuasaan CEO yang berasal dari tenure dan kepemilikan saham memiliki peran penting terhadap interaksi dengan anggota manajemen tingkat atas lain.

Kekuasaan yang dimiliki CEO dapat digunakan untuk mempengaruhi pihak lain untuk mengambil keputusan yang sesuai dengan tujuan CEO. (Feng, Ge, Luo, \& Shevlin, 2011) membuktikan secara empiris bahwa CEO yang memiliki kekuasaan dapat memberikan pengaruh kepada CFO untuk melebihkan kinerja keuangan dan mengubah laporan keuangan. Pengaruh kekuasaan CEO dalam pengambilan keputusan perusahaan juga sesuai dengan upper echelon theory yang diungkapkan oleh (Hambrick \& Mason, 1984) yang menegaskan bahwa keputusan yang ada di dalam perusahaan merupakan keputusan kelompok hasil interaksi antar eksekutif perusahaan. (Adams \& Ferreira, 2009) menambahkan bahwa board yang mempunyai pengaruh di perusahaan merupakan board yang memiliki peran dalam pengambilan keputusan penting. Perusahaan yang memiliki CEO yang berkuasa menunjukkan kinerja yang bervariasi. Interaksi CEO yang memiliki kekuasaan dengan jajaran manajemen tingkat atas perusahaan diduga akan mempengaruhi kenderungan pengambilan risiko bank. Hipotesis dalam penelitian ini mempertimbangkan kekuasaan CEO sebagai variabel pemoderasi terhadap hubungan antara keberadaaan wanita dan risiko bank.

Penelitian ini berkontribusi untuk menguji peran persentase pengawas dan direksi wanita terhadap risiko bank. Penelitian sebelumnya telah dilaksanakan akan tetapi menghasilkan temuan yang belum konklusif. Beberapa penelitian membuktikan secara empiris bahwa board wanita di manajemen tingkat atas perusahaan menurunkan risiko bank (Bernile, Bhagwat, \& Yonker, 2018) (Lees et al., 2015) (Huang \& Kisgen, 
2013) Temuan lain menyatakan bahwa board wanita dapat meningkatkan risiko (Adams \& Funk, 2012) (Akbar, Kharabsheh, Poletti-Hughes, \& Shah, 2017). Selain itu, (Bollen \& Posavac, 2018) menemukan bahwa wanita dan laki-laki memiliki kesamaan dalam pengambilan risiko. Kedua, penelitian ini menjawab gab penelitian sebelumnya yang masih belum konsisten dengan melibatkan peran kekuasaan CEO terhadap hubungan antara persentase pengawas dan direksi wanita dan risiko bank.

\section{Metode Penelitian}

Penelitian ini merupakan penelitian lapangan dengan data yang digunakan berasal dari data sekunder berbagai variabel yaitu pengawas dan direksi wanita, kekuasaan CEO dan risiko bank-bank di Indonesia yang terdaftar di Bursa Efek Indonesia, pada tahun 2013-2017.

Variabel independen dalam penelitian ini adalah pengawas dan direksi wanita, yang merupakan persentase wanita di jajaran dewan komisaris dan dewan direksi perusahaan. Mengacu pada penelitian yang dilakukan oleh (Labelle, Gargouri, \& Francoeur, 2010) formula matematika dari variabel pengawas dan direksi wanita adalah sebagai berikut,

$$
\begin{gathered}
\text { Pengawas dan direksi wanita } \\
=\frac{\text { jumlah wanita di jajaran dawan komisaris dan dawan diraksi }}{\text { jumlah kasaiuruhan dawan komisaris dan diraksi }} \times 100 \%
\end{gathered}
$$

Varibel moderasi dalam penelitian ini adalah kekuasaan CEO. Penelitian ini menguji lebih lanjut bagaimana kekuasaan yang diperoleh CEO dari dalam perusahaan yaitu kontrol manajerial dan kontrol keahlian (Park et al., 2018).

Jenis data yang digunakan pada penelitian ini adalah data sekunder yang diperoleh dari pihak kedua. Data dapat diperoleh dan diunduh dari database, website Bursa Efek Indonesia maupun dari website bank yang bersangkutan. Data yang tidak tersedia atau tidak lengkap akan dikeluarkan dari sampel penelitian. Data yang digunakan pada penelitian ini berupa data digital laporan tahunan perbankan tahun 2012-2017.

Setelah melakukan pengumpulan data, selanjutnya data akan diolah menggunakan analisis regresi dengan bantuan program SPSS. Hasil olahan data akan dianalisis menggunakan statistik deskriptif, uji asumsi klasik dan analisis regresi untuk hasil uji hipotesis. 
Data analisis deskriptif dapat digunakan sebagai acuan dalam menjelaskan hasil analisis dari pengujian hipotesis penelitian. Analisis deskriptif berisi kumpulan data secara statistik rata-rata, standar deviasi, nilai minimum dan nilai maksimum data dari masing-masing variabel (Ghozali, 2007). Sebelum melakukan pengolahan regresi, data harus memenuhi uji asumsi klasik antara lain uji heteroskedastisitas, uji multikolinieritas, uji autokorelasi, uji normalitas.

\section{Hasil dan Pembahasan}

\section{A. Hasil Uji Asumsi Klasik Dan Analisis Regresi Model 1}

\section{Hasil Uji Multikolonieritas}

\begin{tabular}{|c|c|c|c|c|c|c|c|}
\hline \multirow{3}{*}{ Model } & \multicolumn{4}{|c|}{ Coefficients $^{\mathrm{a}}$} & \multirow{3}{*}{ Sig. } & & \\
\hline & \multicolumn{2}{|c|}{$\begin{array}{c}\text { Unstandardized } \\
\text { Coefficients }\end{array}$} & \multirow{2}{*}{$\begin{array}{c}\begin{array}{c}\text { Standardized } \\
\text { Coefficients }\end{array} \\
\text { Beta }\end{array}$} & \multirow[t]{2}{*}{$\mathrm{t}$} & & \multicolumn{2}{|c|}{$\begin{array}{c}\text { Collinearity } \\
\text { Statistics }\end{array}$} \\
\hline & B & Std. Error & & & & $\begin{array}{c}\text { Toleranc } \\
\mathrm{e}\end{array}$ & VIF \\
\hline $\begin{array}{l}\text { (Constan } \\
\text { t) }\end{array}$ & -.264 & .072 & & -3.654 & .000 & & \\
\hline EW & -.242 & .076 & -.249 & -3.192 & .002 & .984 & 1.016 \\
\hline SIZE & -.006 & .010 & -.052 & -.667 & .506 & .990 & 1.010 \\
\hline REVG & .033 & .023 & .113 & 1.425 & .156 & .958 & 1.044 \\
\hline LLPI & -.001 & .002 & -.030 & -.387 & .699 & .971 & 1.030 \\
\hline
\end{tabular}

a. Dependent Variable: RISIKOBANK

\section{Hasil Uji Autokorelasi}

Model Summary

\begin{tabular}{lrrrrr}
\hline Model & $\mathrm{R}$ & R Square & $\begin{array}{c}\text { Adjusted R } \\
\text { Square }\end{array}$ & $\begin{array}{c}\text { Std. Error of the } \\
\text { Estimate }\end{array}$ & Durbin-Watson \\
\hline 1 & $.290^{\mathrm{a}}$ & .084 & .060 & .1199272856591 & 2.093 \\
& & & & 96 & \\
\hline
\end{tabular}

a. Predictors: (Constant), LLPI, SIZE, EW, REVG

b. Dependent Variable: RISIKOBANK

\section{Hasil Uji Heteroskedastisitas}

\section{Coefficients $^{\mathrm{a}}$}

\begin{tabular}{|c|c|c|c|c|c|c|}
\hline \multirow[t]{2}{*}{ Model } & \multicolumn{2}{|c|}{$\begin{array}{l}\text { Unstandardized } \\
\text { Coefficients }\end{array}$} & $\begin{array}{l}\text { Standardized } \\
\text { Coefficients }\end{array}$ & \multirow[t]{2}{*}{$\mathrm{t}$} & \multirow[t]{2}{*}{ Sig. } & $\begin{array}{l}\text { Collinearity } \\
\text { Statistics }\end{array}$ \\
\hline & B & Std. Error & Beta & & & $\begin{array}{cc}\begin{array}{c}\text { Toleranc } \\
\text { e }\end{array} & \text { VIF } \\
\end{array}$ \\
\hline (Constant) & .141 & .043 & & 3.304 & .001 & \\
\hline EW & .037 & .045 & .066 & .818 & .414 & 9841.016 \\
\hline
\end{tabular}




\begin{tabular}{lllrrrrr} 
SIZE & -.006 & .006 & -.088 & -1.094 & .276 & .990 & 1.010 \\
\hline REVG & -.013 & .014 & -.076 & -.935 & .351 & .958 & 1.044 \\
\hline LLPI & -.002 & .001 & -.114 & -1.406 & .162 & .971 & 1.030 \\
\hline
\end{tabular}

a. Dependent Variable: AbsUT

\section{Hasil Uji Normalitas}

One-Sample Kolmogorov-Smirnov Test

\begin{tabular}{llr}
\hline & & $\begin{array}{r}\text { Unstandardiz } \\
\text { ed Residual }\end{array}$ \\
\hline $\mathrm{N}$ & \multicolumn{1}{c}{$\begin{array}{lr}158 \\
\text { Normal Parameters }\end{array}$} \\
\cline { 2 - 3 } & Mean & .0000000 \\
\cline { 2 - 3 } & $\begin{array}{l}\text { Std. } \\
\text { Deviation }\end{array}$ & .11838969 \\
\hline Most Extreme & Absolute & .043 \\
\cline { 2 - 3 } Differences & Positive & .043 \\
\cline { 2 - 3 } & Negative & -.034 \\
\hline Kolmogorov-Smirnov Z & .535 \\
\hline \multicolumn{2}{l}{ Asymp. Sig. (2-tailed) } & .937 \\
\hline
\end{tabular}

a. Test distribution is Normal.

b. Calculated from data.

B. Hasil Uji Asumsi Klasik Dan Analisis Regresi Model 2

\section{Hasil Uji Multikolonieritas}

\section{Coefficients $^{\mathrm{a}}$}

\begin{tabular}{lccccccc}
\hline Model & \multicolumn{2}{c}{$\begin{array}{c}\text { Unstandardized } \\
\text { Coefficients }\end{array}$} & $\begin{array}{c}\text { Standardized } \\
\text { Coefficients }\end{array}$ & $\mathrm{t}$ & & Sig. & \multicolumn{2}{c}{$\begin{array}{c}\text { Collinearity } \\
\text { Statistics }\end{array}$} \\
\cline { 2 - 4 } & \multicolumn{1}{c}{$\mathrm{B}$} & Std. Error & \multicolumn{2}{c}{ Beta } & & & \multicolumn{2}{c}{ Tolerance } & VIF \\
\hline (Constant) & -.273 & .069 & & -3.947 & .000 & & \\
\hline EW & -.331 & .076 & -.340 & -4.374 & .000 & .900 & 1.111 \\
\hline SIZE & -.005 & .010 & -.041 & -.538 & .591 & .940 & 1.064 \\
\hline REVG & .043 & .022 & .146 & 1.925 & .056 & .947 & 1.056 \\
\hline LLPI & -.001 & .002 & -.017 & -.225 & .822 & .938 & 1.066 \\
\hline CT & -.062 & .028 & -.237 & -2.204 & .029 & .472 & 2.117 \\
\hline EWdanCT & .536 & .133 & .434 & 4.039 & .000 & .471 & 2.124 \\
\hline
\end{tabular}

a. Dependent Variable: RISIKOBANK 


\section{Hasil Uji Autokorelasi}

\begin{tabular}{llrcrr}
\multicolumn{7}{c}{ Model Summary $^{\mathbf{b}}$} \\
Model & $\mathrm{R}$ & R Square & $\begin{array}{c}\text { Adjusted R } \\
\text { Square }\end{array}$ & $\begin{array}{c}\text { Std. Error of the } \\
\text { Estimate }\end{array}$ & Durbin-Watson \\
\hline 1 & $.421^{\mathrm{a}}$ & .177 & .145 & .114420468598 & 2.177 \\
\hline
\end{tabular}

a. Predictors: (Constant), EWdanCT, REVG, SIZE, LLPI, EW, CT

b. Dependent Variable: RISIKOBANK

3. Hasil Uji Heteroskedastisitas

Coefficients $^{\mathrm{a}}$

\begin{tabular}{|c|c|c|c|c|c|c|c|}
\hline \multirow[t]{2}{*}{ Model } & \multicolumn{2}{|c|}{$\begin{array}{c}\text { Unstandardized } \\
\text { Coefficients }\end{array}$} & \multirow{2}{*}{$\begin{array}{c}\begin{array}{c}\text { Standardized } \\
\text { Coefficients }\end{array} \\
\text { Beta }\end{array}$} & \multirow[t]{2}{*}{ t } & \multirow[t]{2}{*}{ Sig. } & \multicolumn{2}{|c|}{$\begin{array}{l}\text { Collinearity } \\
\text { Statistics }\end{array}$} \\
\hline & B & Std. Error & & & & $\begin{array}{c}\text { Tolera } \\
\text { nce }\end{array}$ & VIF \\
\hline $\begin{array}{l}\text { (Constan } \\
\text { t) }\end{array}$ & .124 & .041 & & 3.069 & .003 & & \\
\hline EW & .002 & .044 & .004 & .053 & .958 & .900 & 1.111 \\
\hline SIZE & -.003 & .006 & -.045 & -.550 & .583 & .940 & 1.064 \\
\hline REVG & -.005 & .013 & -.029 & -.359 & .720 & .947 & 1.056 \\
\hline LLPI & -.002 & .001 & -.122 & -1.483 & .140 & .938 & 1.066 \\
\hline $\mathrm{CT}$ & -.001 & .016 & -.009 & -.082 & .935 & .472 & 2.117 \\
\hline EWdanC & -.100 & .078 & -.150 & -1.287 & .200 & .471 & 2.124 \\
\hline
\end{tabular}

a. Dependent Variable: AbsUT

\begin{tabular}{|c|c|c|c|c|c|c|c|}
\hline \multicolumn{8}{|c|}{ Coefficients $^{\mathrm{a}}$} \\
\hline \multirow[t]{2}{*}{ Model } & \multicolumn{2}{|c|}{$\begin{array}{c}\text { Unstandardized } \\
\text { Coefficients }\end{array}$} & \multirow{2}{*}{$\begin{array}{c}\text { Standardized } \\
\text { Coefficients }\end{array}$} & \multirow[t]{2}{*}{$\mathrm{t}$} & \multirow[t]{2}{*}{ Sig. } & \multicolumn{2}{|c|}{$\begin{array}{l}\text { Collinearity } \\
\text { Statistics }\end{array}$} \\
\hline & $\mathrm{B}$ & $\begin{array}{l}\text { Std. } \\
\text { Error }\end{array}$ & & & & Tolerance & VIF \\
\hline $\begin{array}{l}\text { (Constan } \\
\text { t) }\end{array}$ & -.242 & .073 & & -3.327 & .001 & & \\
\hline$\overline{E W}$ & -.262 & .076 & -.270 & -3.449 & .001 & .955 & 1.047 \\
\hline SIZE & -.010 & .010 & -.077 & -.954 & .342 & .905 & 1.105 \\
\hline REVG & .039 & .023 & .131 & 1.664 & .098 & .945 & 1.058 \\
\hline LLPI & -.001 & .002 & -.029 & -.374 & .709 & .971 & 1.030 \\
\hline $\mathrm{KS}$ & -.040 & .027 & -.146 & -1.459 & .147 & .585 & 1.709 \\
\hline $\begin{array}{l}\text { EWdanK } \\
\text { S }\end{array}$ & .343 & .145 & .236 & 2.360 & .020 & .587 & 1.703 \\
\hline
\end{tabular}


4. Hasil Uji Normalitas

\begin{tabular}{|c|c|c|}
\hline \multicolumn{3}{|c|}{ One-Sample Kolmogorov-Smirnov Test } \\
\hline & & $\begin{array}{l}\text { Unstandardiz } \\
\text { ed Residual }\end{array}$ \\
\hline $\mathrm{N}$ & & 158 \\
\hline \multirow[b]{2}{*}{ Normal Parameters ${ }^{\mathrm{a}, \mathrm{b}}$} & Mean & .0000000 \\
\hline & $\begin{array}{l}\text { Std. } \\
\text { Deviation }\end{array}$ & .11221279 \\
\hline \multirow{3}{*}{$\begin{array}{l}\text { Most Extreme } \\
\text { Differences }\end{array}$} & Absolute & .041 \\
\hline & Positive & .028 \\
\hline & Negative & -.041 \\
\hline \multicolumn{2}{|c|}{ Kolmogorov-Smirnov Z } & .509 \\
\hline \multicolumn{2}{|l|}{ Asymp. Sig. (2-tailed) } & .958 \\
\hline
\end{tabular}

C. Hasil Uji Asumsi Klasik Dan Analisis Regresi Model 3

1. Hasil Uji Autokorelasi

Model Summary ${ }^{\mathrm{b}}$

\begin{tabular}{lrrrrr}
\hline Model & R & R Square & $\begin{array}{c}\text { Adjusted R } \\
\text { Square }\end{array}$ & $\begin{array}{l}\text { Std. Error of } \\
\text { the Estimate }\end{array}$ & $\begin{array}{l}\text { Durbin- } \\
\text { Watson }\end{array}$ \\
\hline 1 & $.342^{\mathrm{a}}$ & .117 & .082 & .1185518061 & 2.015 \\
& & & & 31879 & \\
\hline
\end{tabular}

a. Predictors: (Constant), EWdanKS, EW, LLPI, REVG, SIZE, KS

b. Dependent Variable: RISIKOBANK

\section{Hasil Uji Heteroskedastisitas}

\section{Coefficients $^{\mathrm{a}}$}



t)

\begin{tabular}{lrrrrrrr}
\hline EW & .017 & .044 & .031 & .388 & .699 & .955 & 1.047 \\
\hline SIZE & -.005 & .006 & -.067 & -.804 & .423 & .905 & 1.105 \\
\hline REVG & -.012 & .014 & -.072 & -.887 & .376 & .945 & 1.058 \\
\hline LLPI & -.002 & .001 & -.123 & -1.533 & .127 & .971 & 1.030 \\
\hline KS & .002 & .016 & .015 & .147 & .883 & .585 & 1.709 \\
\hline EWdanK & -.133 & .085 & -.163 & -1.574 & .118 & .587 & 1.703 \\
S & & & & & & & \\
\hline
\end{tabular}

a. Dependent Variable: AbsUt 


\section{Uji Normalitas}

\begin{tabular}{llr}
\hline \multicolumn{2}{c}{ One-Sample Kolmogorov-Smirnov Test } \\
\hline & \multicolumn{1}{c}{$\begin{array}{c}\text { Unstandardiz } \\
\text { ed Residual }\end{array}$} \\
\hline $\mathrm{N}$ & & 158 \\
\hline \multirow{2}{*}{ Normal Parameters } & Mean & .0000000 \\
\cline { 2 - 3 } & $\begin{array}{l}\text { Std. } \\
\text { Deviation }\end{array}$ & .11626442 \\
\hline Most Extreme & Absolute & .037 \\
\cline { 2 - 3 } Differences & Positive & .033 \\
\cline { 2 - 3 } & Negative & -.037 \\
\hline Kolmogorov-Smirnov Z & .463 \\
\hline Asymp. Sig. (2-tailed) & & .983 \\
\hline a. Test distribution is Normal. & \\
\hline b. Calculated from data. & \\
\hline
\end{tabular}

\section{Analisis Regresi}

Pengujian hipotesis dalam penelitian ini dilakukan dengan menggunakan analisis regresi OLS (ordinary least square) untuk melihat pengaruh dari keberadaan pengawas dan direksi wanita terhadap risiko bank. Model persamaan yang digunakan dalam penelitian ini terdiri dari model 1, model 2 dan model 3 . model 1 berisi persamaan yang digunakan untuk menguji pengaruh variabel independen terhadap variabel dependen. Model 2 dan model 3 menjelaskan persamaan untuk menguji adanya pengaruh variabel moderasi terhadap hubungan antara variabel independen dan variabel dependen. Model 2 menguji pengaruh variabel moderasi kekuasaan CEO dengan indikator CEO tenure sedangkan model 3 menguji pengaruh variabel moderasi kekuasaan CEO dengan indikator kepemilikan saham CEO. Tiga model tersebut adalah sebagai berikut,

$$
\begin{aligned}
& \mathrm{R}=\alpha_{0}+\alpha_{1} \mathrm{EW}+\alpha_{2} \mathrm{SIZE}+\alpha_{3} \mathrm{REVG}+\alpha_{4} \mathrm{LLPI}+\varepsilon \ldots \ldots \ldots \ldots \ldots \ldots \ldots \ldots \ldots \ldots \\
& \mathrm{R}=\alpha_{0}+\alpha_{1} \mathrm{EW}+\alpha_{2} \mathrm{EW} . \mathrm{CT}+\alpha_{3} \mathrm{CT}+\alpha_{4} \mathrm{SIZE}+\alpha_{5} \mathrm{REVG}+\alpha_{6} \mathrm{LLPI}+\varepsilon \\
& \mathrm{R}=\alpha_{0}+\alpha_{1} \mathrm{EW}+\alpha_{2} \mathrm{EW} . \mathrm{KS}+\alpha_{3} \mathrm{KS}+\alpha_{4} \mathrm{SIZE}+\alpha_{5} \mathrm{REVG}+\alpha_{6} \mathrm{LLPI}+\varepsilon
\end{aligned}
$$

Keterangan:

$\mathrm{R}$

:Risiko bank yang diukur dengan z-score

EW :Pengawas dan direksi wanita diukur dengan persentase dewan komisaris dan dewan direksi wanita dibandingkan dengan total dewan komisaris dan dewan direksi wanita di bank 
CT :CEO tenure diukur dengan dummy, yaitu 1 apabila CEO menjabat di perusahaan dengan periode lebih dari 3 tahun dan 0 apabila sebaliknya.

KS :Kepemilikan saham diukur dengan dummy, yaitu 1 apabila kepemilikan saham lebih dari median dan 0 apabila sebaliknya

SIZE :Ukuran bank yang diukur dengan log total aset

REVG :Pertumbuhan pendapatan bank diukur dengan pertumbuhan net interest revenue

LLPI :Rasio total loan loss provision dibagi total loan

$\varepsilon \quad$ :Standar error

\section{Hasil Pengujian Hipotesis dan Pembahasan}

Setelah semua syarat uji asumsi klasik terpenuhi, maka selanjutnya adalah melakukan uji hipotesis. Pengujian hipotesis dilakukan untuk mengetahui pengaruh persentase pengawas dan direksi wanita terhadap risiko bank, dengan variabel kekuasaan CEO sebagai variabel pemoderasi. Pengujian hipotesis pada tabel hasil regresi menunjukkan hasil pengujian sebagai berikut,

Analisis Regresi (Model 1)

\begin{tabular}{lcc}
\hline Model & Koefisien & Signifikansi \\
\hline (Constant) & $-0,264$ & 0,000 \\
\hline Pengawas dan Direksi Wanita (EW) & $-0,242$ & 0,002 \\
\hline Pertumbuhan Bank (REVG) & 0,033 & 0,156 \\
\hline Loan Loss Provision (LLPI) & $-0,001$ & 0,699 \\
\hline Ukuran Bank (SIZE) & $-0,006$ & 0,506 \\
\hline u
\end{tabular}

mber: Hasil olah data menggunakan SPSS IBM 2

Analisis Regresi (Model 2)

\begin{tabular}{lcc}
\hline Model & Koefisien & Signifikansi \\
\hline (Constant) & $-0,273$ & 0,000 \\
\hline Pengawas dan Direksi Wanita (EW) & $-0,331$ & 0,000 \\
\hline Pertumbuhan Bank (REVG) & 0,043 & 0,056 \\
\hline Loan Loss Provision (LLPI) & $-0,001$ & 0,822 \\
\hline Ukuran Bank (SIZE) & 0,005 & 0,591 \\
\hline CEO Tenure (CT) & $-0,062$ & 0,029 \\
\hline Interaksi EW x CT & $-0,536$ & 0,000 \\
\hline
\end{tabular}

Hasil olah data menggunakan SPSS IBM 21 
Hasil regresi hipotesis 1 model 1, model 2 dan model 3 menguji tentang pengaruh persentase pengawas dan direksi wanita terhadap risiko bank dan menunjukkan variabel persentase pengawas dan direksi wanita berpengaruh negatif terhadap risiko bank. Hal ini ditunjukkan dengan nilai koefisien negatif 0.242 dengan nilai signifikansi dibawah $5 \%$ yaitu sebesar 0,002 pada regresi model 1. Hasil regresi model 2 dan model 3 juga menunjukkan hasil yang sama, pada model dua pengaruh pengawas dan direksi wanita terhadap risiko bank ditunjukkan dengan koefisien negatif 0,331 dan nilai signifikansi dibawah $5 \%$ yaitu sebesar 0,0000. Hasil regresi model 3 menunjukkan koefisien eksektif wanita sebesar negatif 0,125 dengan tingkat signifikansi dibawah 5\% yaitu 0,000. Hal ini sesuai dengan hipotesis pertama, sehingga dapat disimpulkan H1 terdukung secara statistik baik pada model 1, model 2 maupun model 3.

Hasil analis regresi model 2 yang bertujuan untuk menguji pengaruh interaksi antara persentase pengawas dan direksi wanita dan CEO tenure terhadap risiko bank. Hasil tabel 4.15 menunjukkan bahwa variabel interaksi pengawas dan direksi wanita dan CEO tenure $(\mathrm{EW} * \mathrm{CT})$ memiliki koefisien negatif $(0,356)$ dengan nilai signifikansi dibawah $5 \%$. Hasil pengujian ini sesuai dengan hipotesis 2a yang menyatakan bahwa hubungan negatif antara pengawas dan direksi wanita dan risiko bank akan semakin lemah, dengan meningkatnya CEO tenure. Kesimpulan yang diperoleh adalah $\mathrm{H} 2 \mathrm{a}$ terdukung secara statistik.

Hasil analis regresi model 3 yang bertujuan untuk menguji pengaruh interaksi antara persentase pengawas dan direksi wanita dengan kepemilikan saham sebagai variabel moderasi. Hasil ini menunjukkan bahwa variabel interaksi pengawas dan direksi wanita dengan kepemilikan saham oleh CEO $\left(\mathrm{EW}^{*} \mathrm{KS}\right)$ memiliki koefisien negatif $(0,356)$ dengan nilai signifikansi dibawah 5\%. Hasil pengujian ini tidak sesuai dengan hipotesis ketiga yang menyatakan bahwa kepemilikan saham CEO memperkuat hubungan negatif antara persentase pengawas dan direktur dan risiko bank. Kesimpulan yang diperoleh adalah h2b tidak terdukung secara statistik. 
Analisis Regresi (Model 3)

\begin{tabular}{lcc}
\hline \multicolumn{1}{c}{ Model } & Koefisien & Signifikansi \\
\hline (Constant) & $-0,242$ &, 001 \\
\hline Pengawas dan Direksi Wanita (EW) & $-0,262$ &, 001 \\
\hline Pertumbuhan Bank (Revg) & 0,039 &, 098 \\
\hline Loan Loss Provision (Llpi) & 0,001 &, 709 \\
\hline Ukuran Bank (Size) & $-0,010$ &, 342 \\
\hline Kepemilikan Saham (KS) & 0,343 &, 147 \\
\hline Interaksi (EW dan KS) & $-0,040$ &, 030 \\
\hline
\end{tabular}

Sumber: Hasil olah data menggunakan SPSS IBM 21

\section{E. Pengaruh Pengawas dan Direksi Wanita Terhadap Risiko Bank}

Hipotesis pertama dalam penelitian ini memprediksi bahwa bank dengan persentase pengawas dan direksi wanita yang tinggi mempunyai risiko bank yang rendah. Hasil regresi hipotesis 1 sesuai yang diharapkan yaitu dengan koefisien bertanda negatif pada model 1, model 2 dan model 3 berturut-turut sebesar negatif $(0,264 ; 0,331$ dan 0,262$)$, dengan nilai signifikansi dibawah $1 \%$ yaitu 0,002 untuk model 1, 0,000 model 2 dan 0,001 model 3.

Berdasarkan hasil penelitian ini, terungkap bahwa persentase pengawas dan direksi wanita berpengaruh signifikan untuk mengurangi risiko bank, temuan ini sejalan dengan penelitian terdahulu yang dilakukan oleh Pahvia, Vahamaa dan Vahamaa (2015). Penelitian tersebut mengungkapkan bahwa CEO dan Chairperson wanita di bank Amerika lebih hati-hati dan menahan level modal yang lebih tinggi untuk mengurangi risiko pada kondisi kejenuhan pasar. Selanjutnya penelitian ini juga mendukung temuan Skala (2017). Skala (2017) mengungkapkan bank yang dipimpin oleh CEO wanita mempunyai risiko bank yang lebih rendah, modal yang cukup dan rasio equity to asset yang lebih tinggi.

\section{F. Pengaruh Interaksi Pengawas dan direksi wanita dengan CEO Tenure terhadap Risiko Bank}

Hipotesis 2a dalam penelitian ini memprediksi CEO tenure yang tinggi akan memperlemah hubungan antara persentase pengawas dan direksi wanita dengan risiko bank. Hasil regresi hipotesis 2 sesuai yang diharapkan yaitu dengan koefisien interaksi antara CEO tenure dan persentase pengawas dan direksi wanita bertanda 
negatif $(0,536)$ pada model 2 , dengan nilai signifikansi dibawah $5 \%$ yaitu 0,029 . Kesimpulan yang dapat diperoleh yaitu semakin lama CEO menjabat di perusahaan memberikan pengaruh terhadap anggota manajemen atas lain di jajaran dewan komisaris dan direktur untuk meningkatkan risiko bank. Hal ini sesuai dengan pernyataan Kim (2011) yang mengungkapkan bahwa CEO merupakan individu yang memiliki pengaruh sangat penting dalam pengambilan kebijakan perusahaan termasuk di dalamnya pengambilan keputusan risiko.

Semakin lama CEO menjabat di perusahaan, kekuasaan CEO semakin meningkat (Park. 2018). Kekuasaan yang dimiliki CEO digunakan untuk memberikan tekanan pada board lain untuk mempengaruhi pengambilan keputusan kinerja perusahaan (Feng dkk. 2011; Cormeir dkk. 2016). Penelitian ini membuktikan bahwa kekuasaan CEO yang tinggi seiring dengan bertambahnya CEO tenure dimanfaatkan oleh CEO untuk mempengaruhi jajaran komisaris dan jajaran direksi serta pengawas dan direksi wanita untuk lebih berani mengambil risiko hal ini ditandai dengan kenaikan risiko bank.

\section{G. Pengaruh Interaksi Pengawas dan direksi wanita dan Kepemilikan saham terhadap Risiko Bank}

Hipotesis $2 \mathrm{~b}$ dalam penelitian ini memprediksi bank dengan CEO yang memiliki saham yang tinggi akan memperkuat hubungan antara persentase pengawas dan direksi wanita dan risiko bank. Hasil regresi hipotesis $2 \mathrm{~b}$ tidak sesuai yang diharapkan yaitu dengan koefisien interaksi antara kepemilian saham dan persentase pengawas dan direksi wanita bertanda positif $(0,289)$ pada model 3 , dengan nilai signifikansi dibawah $5 \%$ yaitu 0,030 . Hal ini menunjukkan bahwa semakin tinggi kepemilikan saham oleh CEO maka hubungan negatif antara pengawas dan direksi wanita dan risiko bank akan semakin lemah. CEO yang memiliki kepemilikan saham yang tinggi akan memberikan pengaruh dan tekanan pada board lain di jajaran dewan komisaris dan direktur untuk meningkatkan risiko bank. 


\section{Kesimpulan}

Tujuan penelitian ini adalah menguji salah satu karakeristik manajerial yaitu persentase pengawas dan direksi wanita terhadap risiko bank di Indonesia priode 20122017. Hasil analisis berdasarkan model 1, model 2 dan model 3 menunjukkan adanya pengaruh negatif pengawas dan direksi terhadap risiko bank. Hal ini mendukung hipotesis pertama penelitian ini yaitu, semakin tinggi persentase pengawas dan direksi wanita maka risiko bank menjadi semakin rendah. Temuan ini menunjukkan bahwa persentase pengawas dan direksi memiliki peran penting dalam menurunkan risiko bank di Indonesia. Implikasi penting dari temuan ini sesuai dengan upper echelon theory yang mengkapkan bahwa output dari organisasi baik berupa strategi maupun keefektifannya merupakan hasil refleksi dari nilai, pengalaman dan karakter personal aktor-aktor yang berada di perusahaan atau faktor psikologis (Hambick dan Mason, 1984). Keberagaman kelompok yang ditandai dengan persentase pengawas dan direksi membawa pada output bank yang memiliki kecenderungan untuk menghindari risiko sesuai dengan karakteristik wanita yang menghindari risiko dan lebih berhati-hati dalam pengambilan keputusan risiko.

Tujuan lain dari penelitian ini adalah menguji pengaruh kekuasaan CEO terhadap hubungan antara pengawas dan direksi wanita dengan risiko bank. Hasil regresi model 2 menunjukkan bahwa indikator kekuasaan CEO yaitu CEO tenure memperlemah hubungan antara pengawas dan direksi wanita dan risiko bank. Ini membuktikan bahwa bank yang memiliki persentase pengawas dan direksi wanita yang tinggi akan memiliki risiko bank yang tinggi apabila di pimpin oleh CEO dengan tenure yang lama. Temuan ini sejalan dengan entrenchment theory yang menyatakan bahwa kekuasaan CEO yang semakin tinggi akan menjadikan CEO semakin entrenched dan meningkatkan kecenderungan pengambilan risiko.

Pengaruh interaksi kekuasaan CEO dengan indikator kepemilikan saham CEO dan persentase pengawas dan direksi wanita ditunjukkan oleh hasil regresi model 3. Hasil ini menunjukkan bahwa kepemilikan saham oleh CEO memperlemah hubungan antara persentase pengawas dan direksi wanita dan risiko bank. Implikasi dari temuan ini adalah bahwa bank yang memiliki persentase pengawas dan direksi wanita tinggi dan kepemilikan saham yang tinggi akan memiliki risiko yang tinggi. Hal ini juga sejalan dengan entrenchment theory. 


\section{BIBLIOGRAFI}

Abbott, L. J., Parker, S., \& Presley, T. J. (2012). Female board presence and the likelihood of financial restatement. Accounting Horizons, 26(4), 607-629.

Adams, R. B., \& Ferreira, D. (2009). Women in the boardroom and their impact on governance and performance. Journal of Financial Economics, 94(2), 291-309.

Adams, R. B., \& Funk, P. (2012). Beyond the glass ceiling: Does gender matter? Management Science, 58(2), 219-235.

Akbar, S., Kharabsheh, B., Poletti-Hughes, J., \& Shah, S. Z. A. (2017). Board structure and corporate risk taking in the UK financial sector. International Review of Financial Analysis, 50, 101-110.

Bernasek, A., \& Shwiff, S. (2001). Gender, risk, and retirement. Journal of Economic Issues, 35(2), 345-356.

Bernile, G., Bhagwat, V., \& Yonker, S. (2018). Board diversity, firm risk, and corporate policies. Journal of Financial Economics, 127(3), 588-612.

Bollen, N. P. B., \& Posavac, S. (2018). Gender, risk tolerance, and false consensus in asset allocation recommendations. Journal of Banking \& Finance, 87, 304-317.

Fahlenbrach, R., \& Stulz, R. M. (2009). Managerial ownership dynamics and firm value. Journal of Financial Economics, 92(3), 342-361.

Feng, M., Ge, W., Luo, S., \& Shevlin, T. (2011). Why do CFOs become involved in material accounting manipulations? Journal of Accounting and Economics, 51(12), 21-36.

Finkelstein, S., Cannella, S. F. B., Hambrick, D. C., \& Cannella, A. A. (2009). Strategic leadership: Theory and research on executives, top management teams, and boards. Oxford University Press, USA.

Francis, B. B., Hasan, I., Wu, Q., \& Yan, M. (2014). Are female CFOs less tax aggressive? Evidence from tax aggressiveness. The Journal of the American Taxation Association, 36(2), 171-202.

Ghozali, I. (2007). Manajemen Risiko Perbankan. Semarang: BPUNDIP.

Greuning, H. v., dan Bratanovic, S. b. (2009). Analyzing Banking Risk. Washington DC: EEI communications.

Hambrick, D. C., \& Mason, P. A. (1984). Upper echelons: The organization as a reflection of its top managers. Academy of Management Review, 9(2), 193-206. 
Huang, J., \& Kisgen, D. J. (2013). Gender and corporate finance: Are male executives overconfident relative to female executives? Journal of Financial Economics, $108(3), 822-839$.

Kim, K. (2010). Blockholder monitoring and the efficiency of pay-performance benchmarking. Journal of Corporate Finance, 16(5), 748-766.

Labelle, R., Gargouri, R. M., \& Francoeur, C. (2010). Ethics, diversity management, and financial reporting quality. Journal of Business Ethics, 93(2), 335-353.

Laeven, L., \& Levine, R. (2009). Bank governance, regulation and risk taking. Journal of Financial Economics, 93(2), 259-275.

Larkin, M. B., Bernardi, R. A., dan Susan M, B. (2013). Does Female Representation on Boards of. Accounting And The Public Interest.

Lees, E. A., Ho, D. K. K., Guiver, M., Mankhambo, L. A., French, N., \& Carrol, E. D. (2015). Comparison of Binax NOW urine antigen test and pneumococcal DNA assay using qPCR before and after nasopharyngeal swabbing in healthy Malawian children. New Microbes and New Infections, 8, 4-6.

Munajim, A., \& Anwar, S. (2016). Faktor Yang Mempengaruhi Keputusan Menjadi Nasabah Bank Syariah. Syntax Literate; Jurnal Ilmiah Indonesia, 1(2), 41-52.

Park, J.-H., Kim, C., Chang, Y. K., Lee, D.-H., \& Sung, Y.-D. (2018). CEO hubris and firm performance: Exploring the moderating roles of CEO power and board vigilance. Journal of Business Ethics, 147(4), 919-933.

PricewaterhouseCoopers. (2008). a new paradigm. Available. Retrieved from http://pwc.com/gx/en/banking-capital-markets/pdf/Reward.pdf.

Walters, B. A., Kroll, M., \& Wright, P. (2010). The impact of TMT board member control and environment on post-IPO performance. Academy of Management Journal, 53(3), 572-595.

Zigraiova, D., \& Jakubik, P. (2015). Systemic event prediction by an aggregate early warning system: An application to the Czech Republic. Economic Systems, 39(4), 553-576. 